\title{
RECORDS OF THE BEAKED WHALE MESOPLODON FROM THE JAPAN SEA
}

\section{AUTHOR(S):}

Nishimura, Saburo; Nishimura, Saburo; Nishiwaki, Masaharu; Nishiwaki, Masaharu

\section{CITATION:}

Nishimura, Saburo .... [et al]. RECORDS OF THE BEAKED WHALE MESOPLODON FROM THE JAPAN SEA. PUBLICATIONS OF THE SETO MARINE BIOLOGICAL LABORATORY 1964, 12(4): 323-334

ISSUE DATE:

1964-12-10

URL:

http://hdl.handle.net/2433/175368

RIGHT: 


\title{
RECORDS OF THE BEAKED WHALE MESOPLODON FROM THE JAPAN SEA ${ }^{13}$
}

\author{
SABURo NISHIMURA \\ Seto Marine Biological Laboratory, Sirahama \\ and \\ MASAHARU NISHIWAKI \\ Whales Research Institute, Tokyo \\ With 2 Text-figures and Plates XXI-XXIV
}

\begin{abstract}
Mesoplodon is the genus most prolific in species of the Odontoceti, with more than ten described species; but most of them are among the rarest and most aberrant cetaceans known to exist. Informations concerning this group of beaked whales are quite scarce, and there still remains a considerable confusion as to the systematics of the genus. Three or four species are now estimated to be distributed in the North Pacific, and all of them are extremely rare, known mostly through merely a few or several records. Hitherto only six scientific records have been made from the surrounding waters of Japan: one from off Sotonoura, Kyûshû (OGawa 1938), one from Oiso, Sagami Bay (Nishiwaki \& KamiYa 1958), three from Ayukawa near Sendai, but two of which are recognized only by mandibles (NISHIWAKI \& KAMIYA 1959; NishiwaKi 1962b) and the rest from near Akita, northwestern Honshu (Nishiwaki 1962a). The specimens from Sotonoura and Ôiso, and one of the three specimens from Ayukawa are considered to be Mesoplodon ginkgodens Nishiwaki \& Kamiya, while as to other specimens there have been some taxonomic confusions as stated later in this paper.

It was rather unusual in the spring of 1963 when no less than three specimens of Mesoplodon were caught in the Japan Sea by commercial fishing boats. Two of these fortunately came under the observation and measurement of the first author, who also succeeded to take some photographs of the fresh specimens of this rare genus. It seems worthwhile to mention here shortly how these specimens caught the author's attention and then were disposed of.
\end{abstract}

1) Contributions from the Seto Marine Biological Laboratory, No. 428.

Publ, Seto Mar, Biol, Lab., XII (4), 1964, (Article 25) 
On April 24, 1963, the first author, belonging to the Japan Sea Regional Fisheries Research Laboratory at Niigata at that time, received a telephonic information from the fish market of the First Fisheries Co-operative Association at Yanagishima, Niigata, telling him that a whale had been captured by a fishing boat of the association and asking for his visit to identify the whale before it was treated. To tell the truth, this information did not excite the first author at first, because it seemed very likely that the whale might be a false killer, Pseudorca crassidens (OwEN), which is a species of the toothed whales caught rather commonly along the west coast of Honshû as well as around Kyûshû Island and in the Tsushima Straits. Therefore he was greatly excited when he found at the fish market that the whale was an adult male of the rare beaked whale Mesoplodon, provided with a pair of large characteristic teeth on the lower jaw (Text-fig. 2 and Figs. 1 and 2, Pl. XXI). It was told that the whale had been captured by a salmon drift net fishing boat in the central part of the Japan Sea. So far as he was aware, this might be the second record of occurrence from this sea, thus constituting a very precious material. So he quickly started to take measurements and records of the whale body before the treating was set on, and at the same time asked the manager of the association to spare the animal head for a skull specimen, and this was accepted. So the first author collected, after the treating was completely over, the tail flukes, the penis and some vertebrae in addition to the head, and brought all of them to his laboratory.

At the laboratory, further examinations were made on the head and tail flukes and some additional photographs were taken; and then the head was sunken on the bottom of a river flowing just near-by for making a skull specimen.

Less than twenty days after the above-mentioned encounter with Mesoplodon, the first author was startled again at a telephone from Mr. Isao Окасні, who was then one of his colleagues at the Japan Sea Regional Fisheries Research Laboratory and happened to visit the fish market of Yanagishima on May 11 to find a beaked whale of a very similar appearance with the previously referred specimen of Mesoplodon but of a much smaller size being landed there. Of course the first author immediately hurried to the fish market and confirmed that the whale was a young female of the same ziphioid genus. This time, too, he made measurements and observations on the whole body of the specimen and took several photographs on the market floor, and again succeeded in obtaining the head, which was later disposed of in the same way as in the previous case.

Quite unfortunately, however, all of these precious specimens were lost in the catastrophe by the great earthquake and tsunami which attacked the district of Niigata on June 16, 1964. Only the mandible of the young female 
had been studied by the last author before the material was destroyed, and some of the records of measurements and observations on the external morphology of both individuals and several photographs illustrating their appearance in a fresh state escaped from being lost since they had been brought to Sirahama when the first author got his new post about two months before the disaster. These records of measurements and observations and some photographs are to be published in this paper, together with certain distributional aspects of this rare whale and the discussion concerning the identification of these specimens as well as some taxonomic notes on certain specimens of the same genus previously recorded from Japan.

The authors' gratitude is due to Mr. Koвayashi of the First Fisheries Co-operative Association at Yanagishima and Mr. KANEKo of the Niigata Coldstorage Company for their kindness in laying the animals under measurements and observations and further in forwarding the heads for skull preparation, to Messrs. KashiWAZAKI and TAIJô, captains of the salmon drift net boats, for their kind informations about the dates and places of capture, to Messrs. I. Okachi, M. Okiyama, T. Uyeno and other member personnel of the Japan Sea Regional Fisheries Research Laboratory for their co-operation in measuring, transporting and disposing the animals, to Dr. I. YamanaKa of the same laboratory for the information about his observations on another specimen of Mesoplodon met with in the northern part of the Japan Sea while he was engaged in offshore salmon fishery investigations, and to Messrs. Igarasi and ÔHra, pressmen of the Niigata Nippô Newspaper, who generously offered some nice photographs of the whale in landing. The authors are also grateful to Prof. H. Utinomi and Dr. T. TokiokA of the Seto Marine Biological Laboratory for their kindness in reading the manuscript.

\section{Date and Place of Capture}

The male specimen was captured on April 23, 1963, 97 nautical miles northwest off Cape Hajiki Zaki of Sado Island, being entangled by the offshore salmon drift gill net which was set just beneath the sea surface at night when the salmon shoals went up near the sea surface from their swimming layer maintained comparatively deep in the daytime. According to Mr. Yoshikatsu KASHIWAZAKI, the captain of the fishing boat, the setting of the net was ended at about 18:00 in the evening of the day before and the pulling-up was begun at 24:00, and it was at about $02: 00$ in the following morning when the whale was found entangled in the net. The animal was caught with its tail flukes twined by the lower fringing rope of the net bearing sinks, which was usually adjusted to be kept at about $6 \mathrm{~m}$ deep during the operation; the whale was killed after two hours' resistance and brought to Niigata being bound to 
the boat-side. The surface water temperature was $9.4^{\circ} \mathrm{C}$ at the place of capture. It was said that the dissected stomach was nearly empty.

The female whale was captured on May 10, 1963, at a little southeast of the Yamato Tai Bank lying at about $39^{\circ} \mathrm{N}$., $135^{\circ} \mathrm{E}$. in the central part of the Japan Sea. According to Mr. Takeshi TAIJô, the captain of the salmon fishery boat, the whale was found entangled dead when the net was pulled up. This rather small individual was brought on board the boat to Niigata to be disposed of, and the stomach was found to be empty, too.

It must be worthwhile to refer here to a record of another individual of Mesoplodon made by Dr. Ichiro YAMANAKA* in the same season, although neither measurement nor close examination was made on this individual. On board the R. V. Takuyô Maru of the Otaru Fisheries High School, Dr. Yamanaka witnessed a salmon fishery boat of Yamagata Prefecture sailing near-by with a whale hung upon the mast, a very strange whale having a pair of fan-shaped teeth on the lower jaw. This was on May 8,1963 , and at $40^{\circ} 29^{\prime} \mathrm{N}$., $137^{\circ} 45^{\prime} \mathrm{E}$. Undoubtedly the whale is a Mesoplodon, and this is the third record of occurrence of the same genus in the season under consideration. Although the exact size of the whale was unknown, it is apparent that the animal that was hung upon the mast of a fishing boat was not of a big size. Dr. Yamanaka observed still another whale swimming at $40^{\circ} 51^{\prime} \mathrm{N}$., $138^{\circ} 04^{\prime} \mathrm{E}$. during the same cruise; but it was not cleared whether it was a Mesoplodon or not.

These three records of occurrence of Mesoplodon are put on the map of the Japan Sea (Text-fig. 1) with the surface isotherms during the period from late April to early May, 1963, and also together with a single previous record of Mesoplodon ( $=$ M. stejnegeri TRUE; see the last section of this paper) from the Japan Sea, which was made on a stranded individual. At these three records one may notice at once that all of them were made in the temperature zone around $10^{\circ} \mathrm{C}$. This might be attributable partly to the fact that the salmon fishing boats operate generally in narrow zones of the surface water temperature around $10^{\circ} \mathrm{C}$ (Sнгмомura 1960,1961 ), but also it might reflect the actual distributional aspect of the whale in the Japan Sea during that season. Especially it must be noted that all of the animals were caught by salmon fishing boats, being entangled in the drift gill net, as this alludes the possibility that the Mesoplodon might have been migrating in close connection with salmon shoals, or more concretely speaking, the whale might have been pursuing salmon shoals as a rapacious predator. For instance, Mr. KASHIWAZAKI is of the opinion that the whale must have approached the net to eat salmon caught in the net. The salmon shoals under consideration consist of Oncorhynchus gorbuscha (WALBAUM) and O. masou (BREVOORT); they are known to make their

\footnotetext{
* Then a fisheries statistician at the Japan Sea Regional Fisheries Research Laboratory.
} 
first appearance in the waters around the Yamato Tai Bank in the central part of the Japan Sea in late February to March, gradually approach the coast of Honshû Island during April to May, and by the end of May most shoals

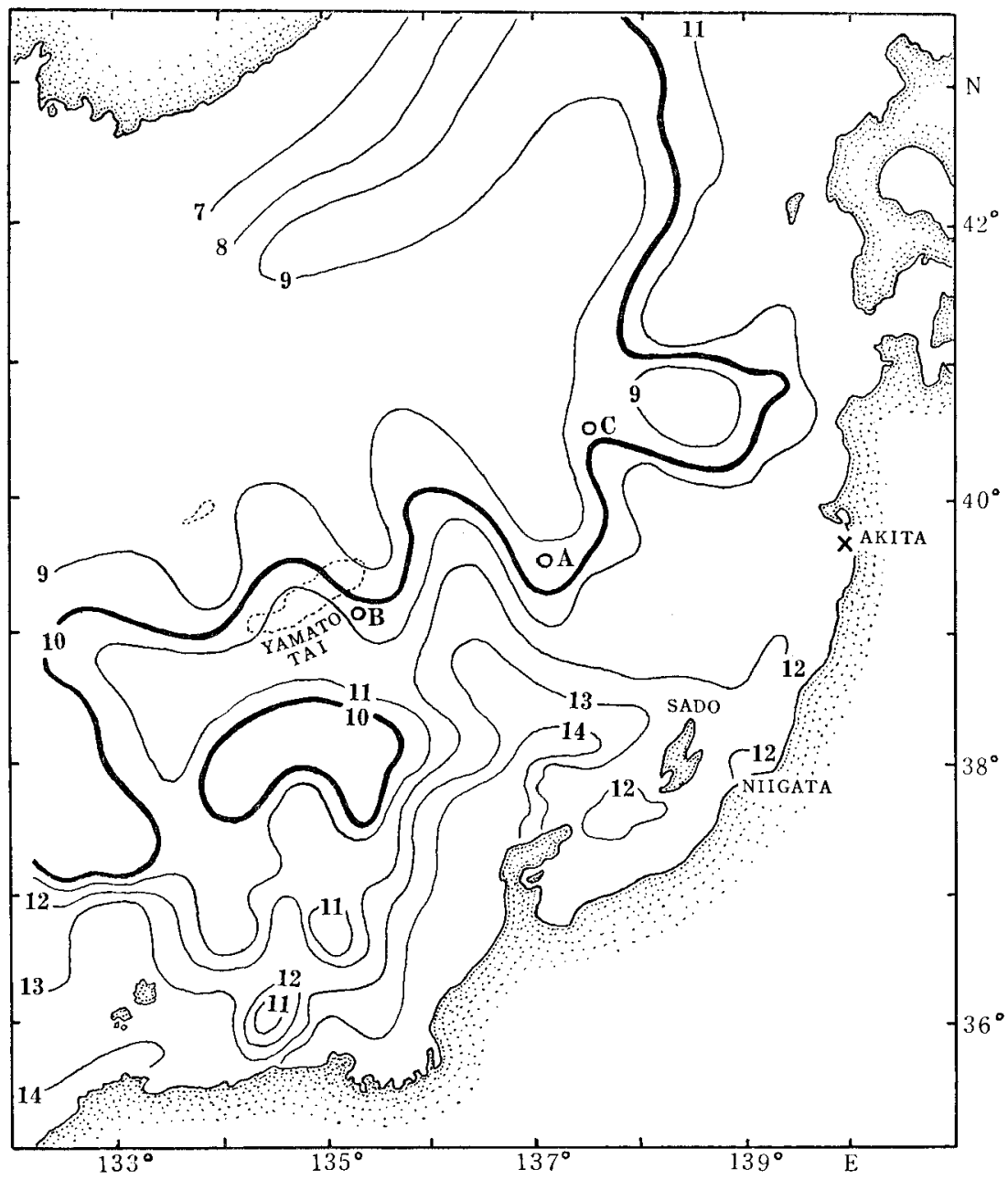

Text-fig. 1. Map showing positions of occurrences of Mesoplodon in the Japan Sea, together with contours of the surface isotherms in centigrade during the period from late April to early May, 1963. A.-Occurring station of the male specimen; B.-Occurring station of the female specimen; C.-Station where another Mesoplodon specimen was observed by I. YAMANAKA. Cross indicates the site of the stranding of Mesoplodon, a single previous record from the Japan Sea.

reach the waters just off the northwestern coast of the Japan Mainland (Shimomura 1960). The record of the stranded individual on the coast near Akita on May 22, 1960 (Nishiwaki 1962a), may be attributable to a stray whale 
from the herd migrating northward off the Honshu coast in pursuit of salmon shoals.

Almost nothing is known about the feeding habit of Mesoplodon. Some authors believe that the whale may probably feed on cephalopods (TomILIN 1962). However, it is not impossible that the animal also attacks and devours pelagic fishes such as salmon. ScheFfer \& SLIPP (1948) mentioned that in Neah Bay near Seattle, U.S.A., solitary individuals or small groups each consisting of less than three individuals of Mesoplodon stejnegeri TRUE were observed within half a mile from the shore chasing anadromous salmon shoals.-By NISHIMURA.

\section{Measurements and External Characters}

Measurements of the body parts of the two Mesoplodon specimens here reported are shown in Table 1.

The male specimen was provided with a pair of teeth on the mandible, which were large, moderately thick and fully exposed. In the female specimen, on the other hand, the teeth were completely embedded in the gum and invisible from the outside, the existence being confirmed only by dissection.

Based on the results of measurements and observations, the gross external appearance of the male specimen is figured as shown in Text-fig. 2.

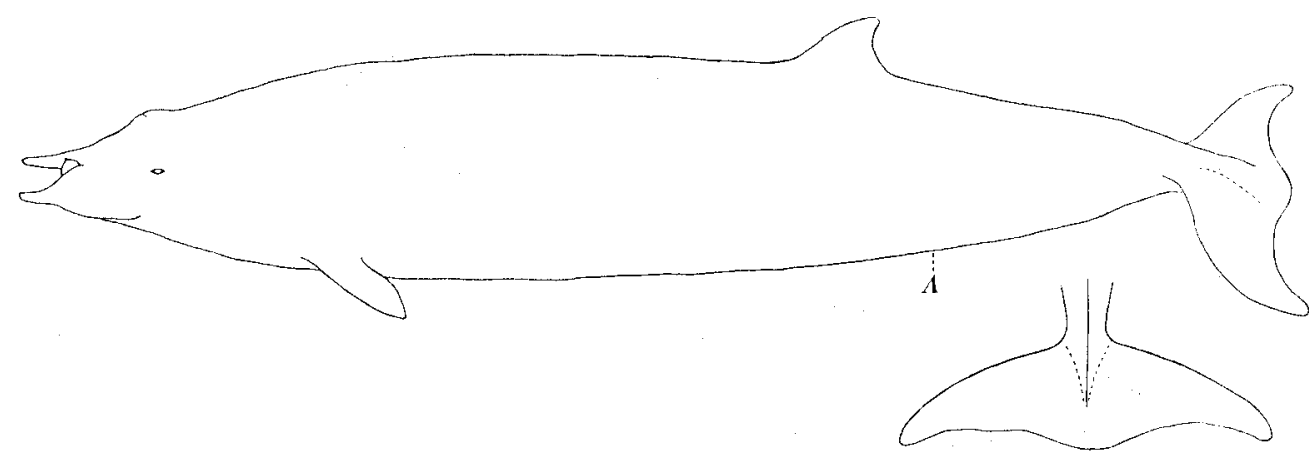

Text-fig. 2. Gross external appearance of the male specimen, based on the results of measurements and on the photographs. $A$ indicates the position of anus.

The male specimen on the market floor was first dark grey all over the body except for the posterior part of the dorsal side including the fin and for the posterior half of the ventral side which were tinged with whitish flesh. Those whitish portions were probably the appearance due to abrasions occurred during the transportation of the animal. The most peculiar was that the ground color of the whale became gradually darker with time so that in two days the coloration turned jet-black (Figs. 3 to 6 , Pl. XXII). The similar postmortem color change was observed on the female specimen, too: on the market 
Table 1. Measurements of body parts of the two specimens of Mesoplodon captured in the Japan Sea. All measurements are given in centimeters. $R$ and $L$ indicate that the items were measured on the right and the left side, respectively.

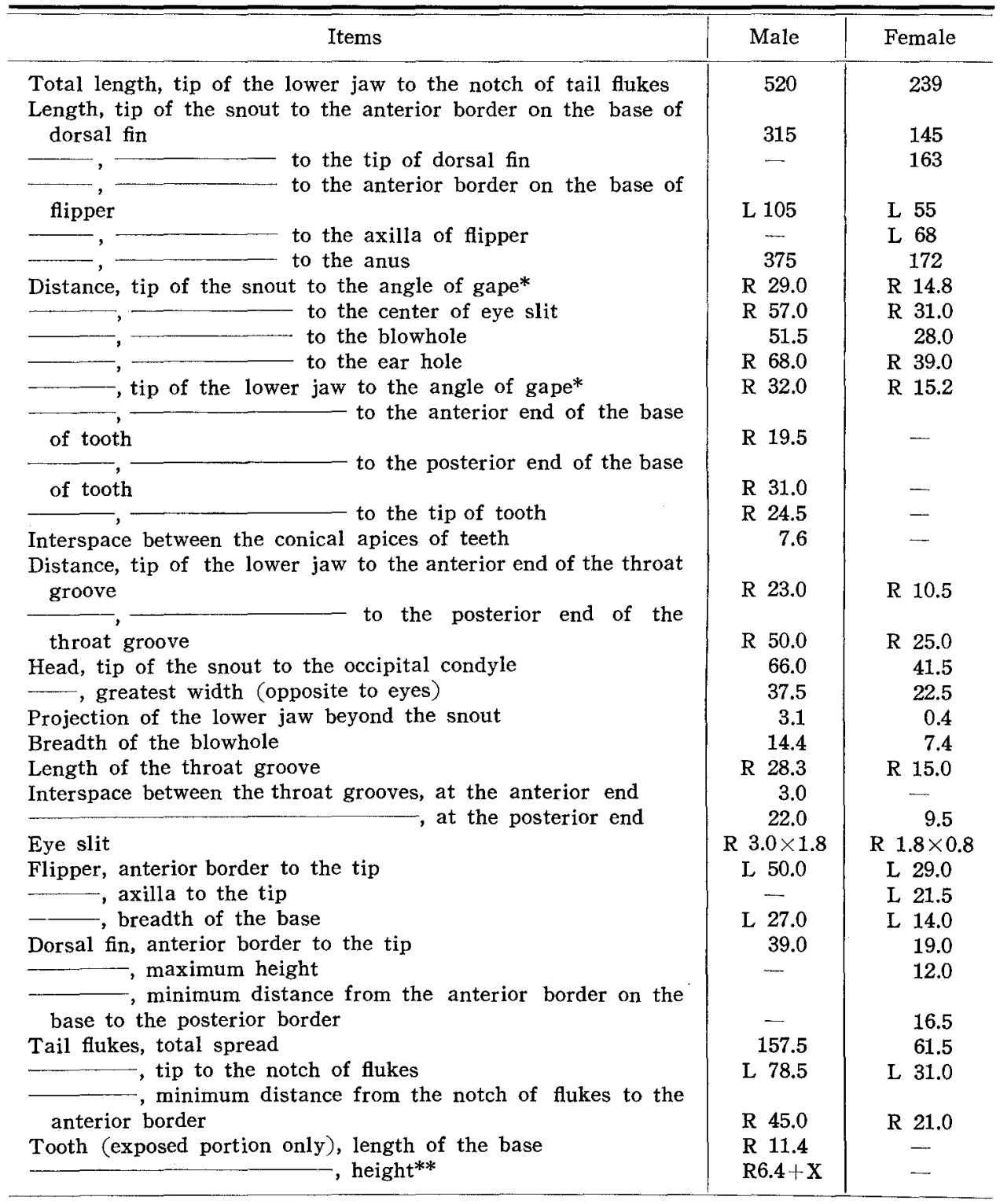

* The distance from the tip of the snout or the lower jaw to the angle of gape was measured to the inner margin of the angle of gape when the mouth cleft was held opening.

** The apex of both teeth was slightly damaged. 
floor, this individual was first grey on the dorsal surface as well as the areas around eyes and snout, and the upper surfaces of flippers and tail flukes, but whitish on the ventral side of the body including the under surface of flippers and tail flukes; and the coloration was found much deepened on the next day (Figs. 7 to 10, Pl. XXIII ; Figs. 11 to 14, Pl. XXIV). It may possibly be surmised that the body color of live whales must have been of a lighter tint than that observed at the fish market.

On the body surface of the male specimen, particularly on its dorsal side, there were found many white, variously curved streaks. They are formed mostly by paired curves running in parallel with a space of about $8 \mathrm{~cm}$ between (Fig. 1, Pl. XXI). This space coincides roughly with the inter-apical space of the teeth of the same animal (cf. Table 1), and this renders a supposition that such streaks are nothing but scars formed by other full-grown males during plays or fightings. The female specimen, on the other hand, showed no traces of such streaks.

It may be of some interest to note that the tongue was colored whitish in the female specimen except for the anterior part which was colored black and frilled on lateral sides with tufts of protuberances. According to JonSGÅRD \& H $\phi$ IDAL (1957), Mesoplodon bidens (Sowerby), an Atlantic congener, attains about $3 \mathrm{~m}$ in the end of the nursing stage. It seems, therefore, very likely that the female specimen measuring $239 \mathrm{~cm}$ in total length was still a sucking infant.

On the outer surface near the posterior side of each tooth in the male specimen there was found a round mark of about a $3-\mathrm{cm}$ diameter, possibly indicating the attachment of an epizoic animal there (Fig. 2, Pl. XXI). As the epizoic animal body had been lost completely, any definite statement cannot be made about the animal that left this mark, but it is not impossible that the marks may have been printed by a species of Conchoderma, a stalked barnacle. According to TARAsov \& Zevina (1957), C. auritum (L.) is found throughout the world oceans from tropical to polar seas, attaching to whales or some pelagic fishes. Tomilin (1936) mentions on rich occurrences of the same barnacle upon the teeth of the sperm whale, Physeter catodon L., in the Kamchatkan waters, and SERGEANT \& Fisher (1957) describes a specimen of Mesoplodon bidens (Sowerby) from the eastern Canadian waters, whose teeth were carrying Conchoderma sp.-By NISHIMURA.

\section{Taxonomic Positions of the Present Specimens}

As mentioned above, all of these specimens were lost by a natural calamity before the skulls were studied in detail. Fortunately some body parts were measured by the first author. The outer measurements of many specimens, including four previously reported Japanese specimens, are very limited. These 
measurements therefore could not be used to determine the species of the present specimens. It is quite a disappointment, but the loss was inevitable. The authors have several pictures of the present specimens before the removal of blubber, so they would like to discuss the taxonomic features of these specimens pictured.

Before the estimation of the species of the present specimens, the names of the species collected previously in Japan should be explained here. The Mesoplodon specimens collected in Japan are four and they were presumed to represent three species by the last author. They are as follows:

M. ginkgodens Nishiwaki \& KamiYa, 1958

Ôiso specimen and Sotonoura specimen (=OGAWA specimen) (Nishiwaki \& KAMIYA:

"A beaked whale Mesoplodon stranded at Oiso beach, Japan". Sci. Rep. Whales Res.

Inst., No. 13, 1958).

M. stejnegeri TRUE, 1885

Ayukawa specimen (NISHIWAKI \& KAMIYA: "Mesoplodon stejnegeri from the coast of Japan." Sci. Rep. Whales Res. Inst., No. 14, 1959).

M. bowdoini ANDREws, 1908

Akita specimen (NISHIWAKI: "Mesoplodon bowdoini stranded at Akita beach, Sea of Japan." Sci. Rep. Whales Res. Inst., No. 16, 1962).

When the Ayukawa specimen was identified, the last author noticed the following two characteristics which differ from those of other specimens-the beak was massive and conspicuously arched upward, and the maxillary prominence was well developed at the inside of the antorbital tubercle. But at that time he considered that these characteristics might be due to the unusually advanced age of the specimen. If he had more informations and could study more deeply with regard to these characters, he would have been aware that it represented a new species.

When the last author indentified the Akita specimen, he placed emphasis on the tooth characteristics, especially on the absence of anterior convexity in the profile of the tooth, the absence of an abrupt shoulder in the posterior margin (note that the tooth of $M$. bowdoini has a fairly divergent character from this specimen), and the tooth thickness. The report "First records of two beaked whales, Mesoplodon bowdoini and Ziphius cavirostris, from the Pacific coast of the United States" by HubBs in 1946 placed importance on the geographical distribution and on the skull shape of M. bowdoini. (HubBs' specimen was later determined as a type specimen for $M$. carlhubbsi by Moore; see MOORE, 1963). For this reason the last author originally considered the Akita specimen as $M$. bowdoini.

However, reading MooRe's paper "Recognizing certain species of beaked whales of the Pacific Ocean" (1963) and moreover discussing the problem in detail with Dr. Moore who visited Japan in February 1964, the last author accepted Moore's new species $M$. carlhubbsi as a valid one and redesignated the Japanese specimens as follows: 
The Ayukawa specimen (formerly as $M$. stejnegeri) is $M$. carlhubbsi Moore, 1963 and the Akita specimen (formerly as $M$. bowdoini) is M. stejnegeri TRUE, 1885.

In the determination of species of the genus Mesoplodon all the preceding literatures must be examined ; besides it is very important to make comparison of respective specimens actually. It was indeed admirable, therefore, that Dr. MOORE traveled around the world for the purpose of studying Mesoplodon solely. The forthcoming publications by him are anticipated earnestly.

Now the last author would like to explain the taxonomic position of the present specimens. Mesoplodon stejnegeri, M. bowdoini, M. ginkgodens, M. carlhubbsi and $M$. densirostris are considered important in relation to the present concern.

On the male specimen, the anterior convexity of the tooth is considered absent (Fig. 3, P1. XXII). Therefore this is neither M. carlhubbsi nor M. ginkgodens. The male $M$. densirostris has a more massive mandible and the tooth is rather smaller than in the present male specimen, and the apex of tooth points backward; thus this species is also eliminated. The remaining species are $M$. stejnegeri and $M$. bowdoini. The distribution and the shape of the tooth, however, suggest the identity of the present male specimen with M. stejnegeri. The Akita specimen was very similar with the present specimen in these criteria.

The last author made really observations and measurements by himself on the mandible and teeth of the present female specimen and took some photographs. But this specimen was a young immature female with only a $239-\mathrm{cm}$ body length; hitherto he has observed several skulls of young immature Mesoplodon only to find that it is nearly impossible to determine their species. It is considered, however, that the present female specimen is probably a young M. stejnegeri because of the forementioned circumstances.*-By NISHIWAKI.

\section{REFERENCES}

HubBs, C. L. 1946. First records of two beaked whales, Mesoplodon bowdoini and Ziphius cavirostris, from the Pacific coast of the United States. J. Mammal., Vol. 27 : 242-255.

JoNSGÅn, A. \& HфIDAL, P. 1957. Strandings of Sowerby's whale (Mesoplodon bidens) on the west coast of Norway. Norw. Whal. Gaz., No. 9 : 507-512.

MOORE, J. C. 1963. Recognizing certain species of beaked whales of the Pacific Ocean. Am. Midl. Nat., Vol. $70: 396-428$.

NishIWAKI, M. 1962a. Mesoplodon bowdoini stranded at Akita beach, Sea of Japan. Sci. Rep. Whales Res. Inst., No. 16: 61-77.

1962b. Observation on two mandibles of Mesoplodon. Ibid., No. 16: 79-82.

* Dr. Benson of the University of California, Berkeley, whom the last author visited in the autumn of 1963, explained his theory on Mesoplodon systematics that the species found in the North Pacific might be united into a single species. This opinion is considered very remarkable, but too progressive in the present stage of investigation. 
Nishiwaki, M. \& Kamiy A, T. 1958. A beaked whale Mesoplodon stranded at Ôiso beach, Japan. Ibid., No. $13: 53-83$.

No. $14: 35-48$.

OGAwA, T. 1938. Studien über die Zahnwale in Japan, insbesondere über die vier bei uns bisher unbekannten Gattungen Tursiops, Steno, Pseudorca und Mesoplodon. Arb. Anat. Inst. Kaiserl. Japan. Univ. Sendai, Hft. 21 : 173-218.

Scheffer, V. B. \& Slipp, J. W. 1948. The whales and dolphins of Washington State, with a key to the cetaceans of the west coast of North America. Am. Midl. Nat., Vol. 39: 257-337.

Sergeant, D. E. \& Fisher, H. D. 1957. The smaller Cetacea of eastern Canadian waters. J. Fish. Res. Bd. Canada, Vol. 14: 83-115.

SHImomura, T. 1960. [Fishing ground in the polar frontal zone of the Japan Sea in the spring of 1959]. Studies on the Fishing Ground in the Polar Frontal Zone of the Japan Sea, 1959: 17-58. (In Japanese).

1961. [Fishing ground in the polar frontal zone of the Japan Sea in the spring of 1960]. Ibid., 1960: 26-111. (In Japanese).

Tarasov, N. I. \& Zevina, G. B. 1957. [Fauna USSR; Crustacea Vol. 6, No. 1 : Cirripedia of the seas of the USSR]. Izd. Akad. Nauk SSSR, Moskva \& Leningrad. (In Russian).

Tomitin, A. G. 1936. [Sperm whales of the Kamchatkan waters]. Zool. Zhur., Tom 15: 483519. (In Russian).

1962. [Whales of the fauna of the seas of the USSR]. Izd. Akad. Nauk SSSR, Moskva \& Leningrad. (In Russian). 


\section{EXPLANATION OF PLATES XXI-XXIV}

Fig. 1. Landing of the male Mesoplodon at the fish market at Yanagishima, Niigata. The animal was hung upside-down by a crane. Note white paired streaks running in parallel and curving variously on the dorsal surface of the body. By courtesy of the Niigata Nippô Newspaper Co.

Fig. 2. Left profile of the male specimen, showing a characteristic fan-shaped tooth on the lower jaw. Note the mark on the tooth indicating the site of attachment of an epizoic animal. The same mark was also noted on the right tooth, but this was scraped off just after this photograph had been taken. By courtesy of the Niigata Nippô Newspaper Co.

Fig. 3. Right profile of the male specimen. Note the absence of the anterior convexity of the tooth.

Fig. 4. Throat of the male specimen.

Fig. 5. Frontal view of the head of the male specimen.

Fig. 6. Dorsal view of the tail flukes of the male specimen. The notch of tail flukes is absent.

Fig. 7. Dorsal view of the female specimen lying on the floor of the fish market.

Fig. 8. Right profile of the female specimen. Teeth were invisible from the outside.

Fig. 9. Throat of the female specimen. The color of the ventral side was much paler.

Fig. 10. Dorsal view of the head of the female specimen.

Fig. 11. Dorsal surface of the right flipper of the female specimen.

Fig. 12. Right side of the dorsal fin of the female specimen.

Fig. 13. Dorsal view of the tail flukes of the female specimen.

Fig. 14. Frontal view of the head of the female specimen. 
Publ. Seto Mar. Biol. Lab., XII, 4 (1964)


S. Nishimura \& M. Nishiwaki: Records of Mesoplodon from the Japan Sea. 

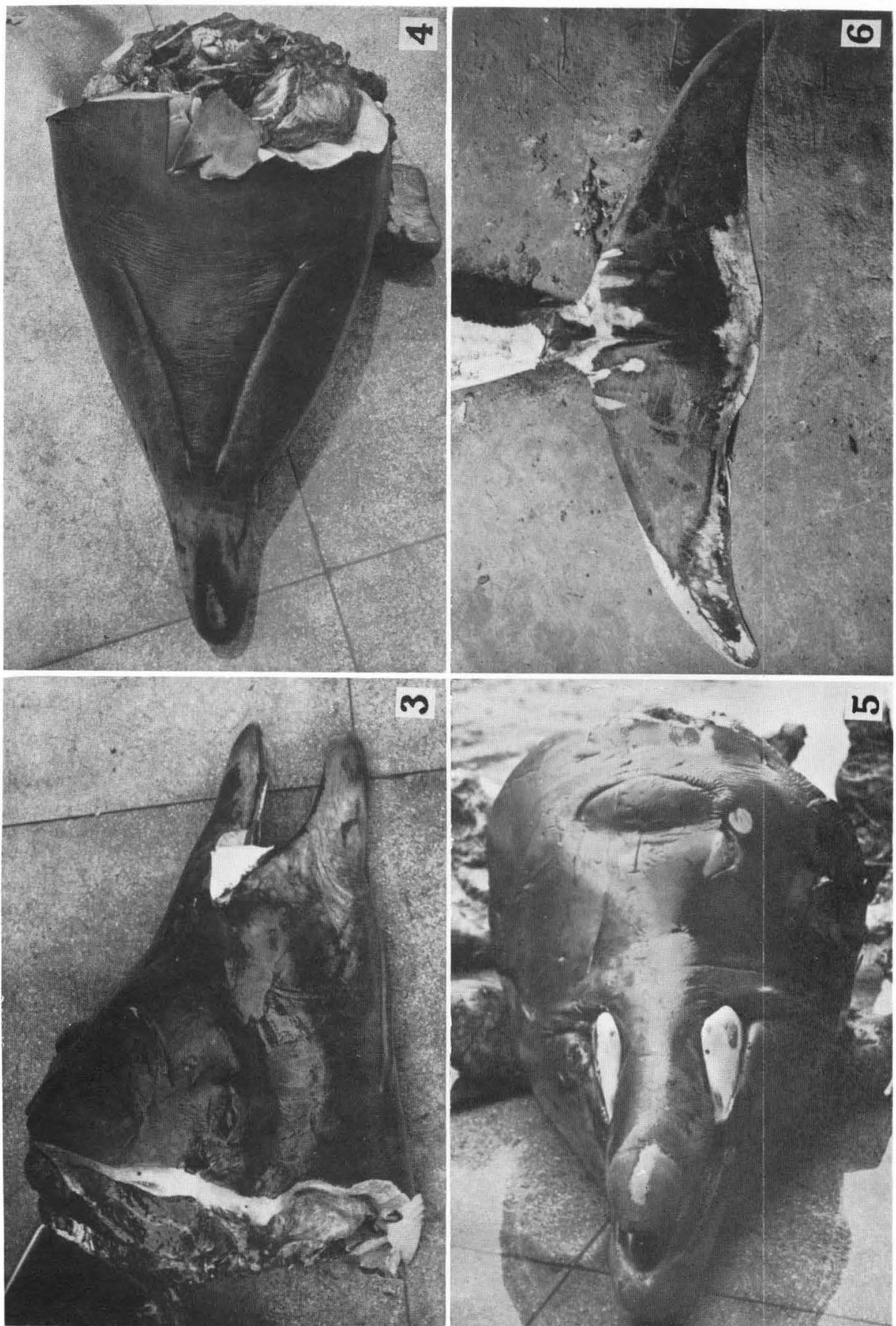

S. Nishimura \& M. Nishiwaki: Records of Mesoplodon from the Japan Sea. 
Publ. Seto Mar. Biol. Lab., XII, 4 (1964) PLATE XXIII

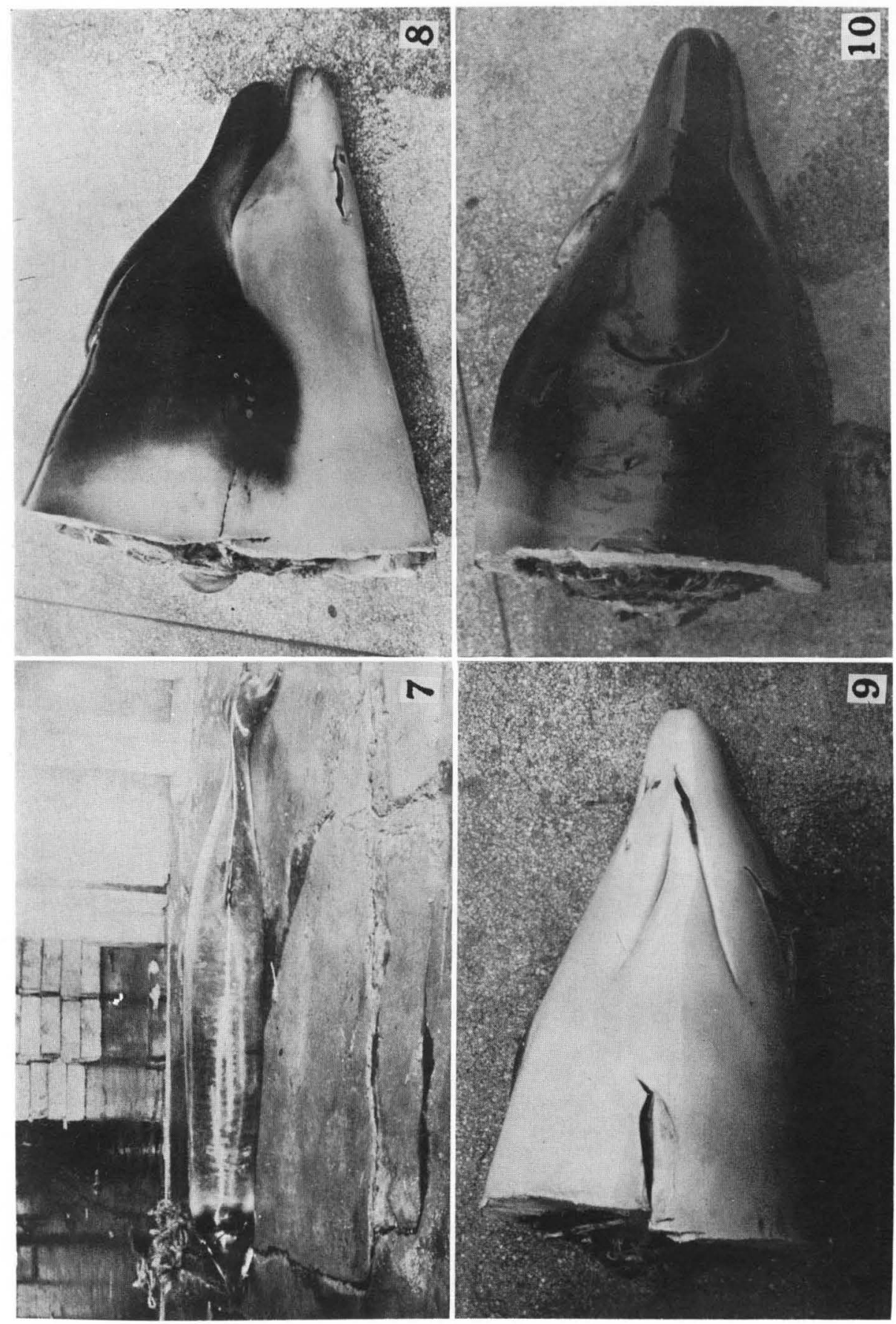

S. Nishimura \& M. Nishiwaki: Records of Mesoplodon from the Japan Sea. 
Publ. Seto Mar. Biol. Lab., XII, 4 (1964)
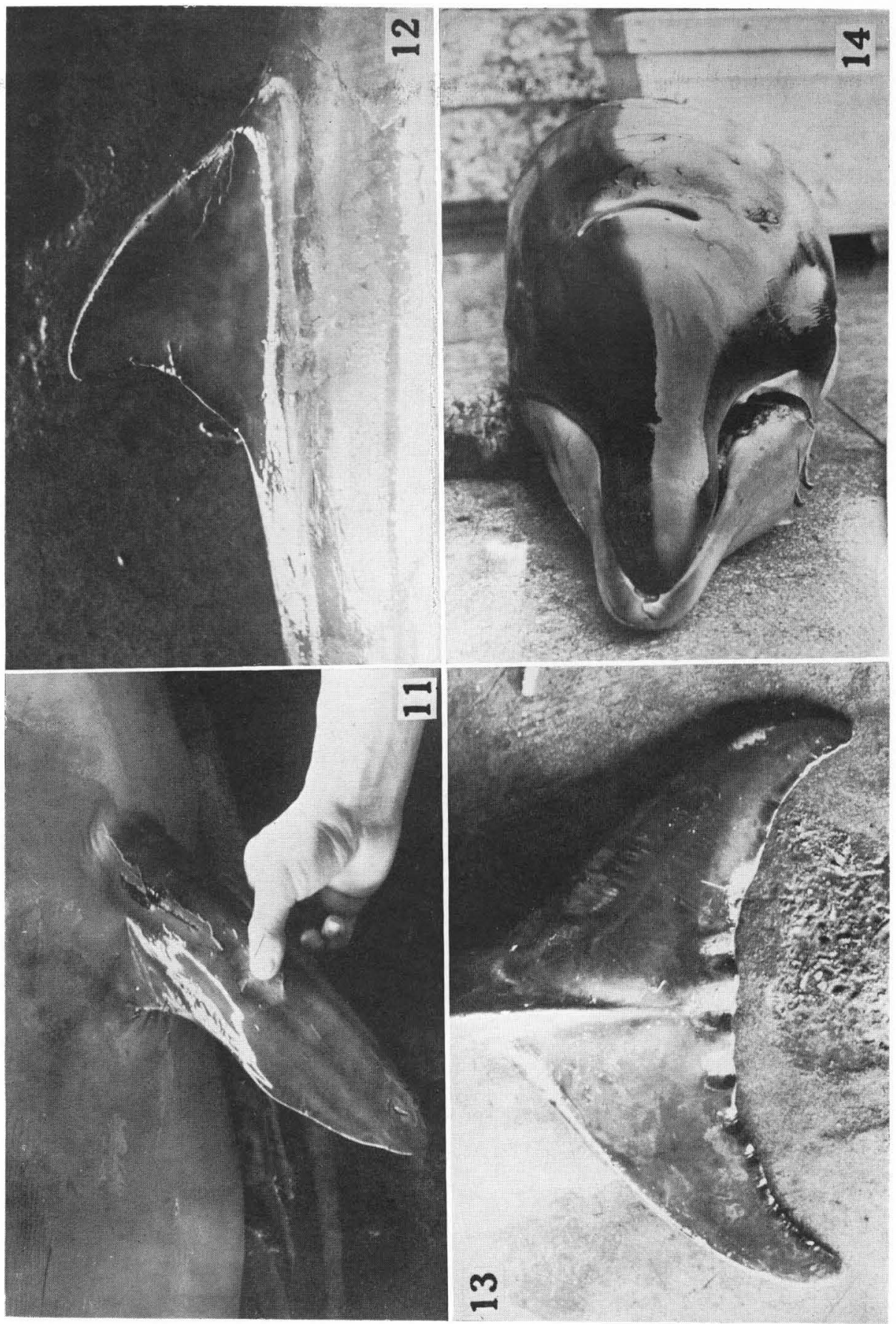

S. Nishimura \& M. Nishiwaki: Records of Mesoplodon from the Japan Sea. 